DOI: $10.19195 / 0137-1134.115 .7$

\title{
EWA ZADECCKA
}

ORCID: 0000-0002-5184-5957

Uniwersytet Ekonomiczny w Krakowie

\section{BEZWZGLĘDNY ZAKAZ REKLAMY KANCELARII ADWOKACKICH W REALIACH WSPÓŁCZESNEGO FUNKCJONOWANIA RYNKU USŁUG PRAWNICZYCH}

\begin{abstract}
Abstrakt: Prowadzenie kancelarii adwokackiej we współczesnych realiach funkcjonowania rynku usług prawniczych jest nie lada wyzwaniem. Adwokat musi nie tylko mieć wiedzę prawniczą, lecz także wykazać się znajomością mechanizmów rynkowych. Dzisiaj to klient decyduje, którego adwokata wybierze, co wymusza konieczność aktywnych działań w celu pozyskiwania klientów i ich utrzymania. Dlatego też coraz częściej wykorzystuje się instrumenty marketingowe (typowe dla innych rynków usług) w budowaniu i uzyskiwaniu przewagi rynkowej. Jednak na rynku usług prawniczych istnieją liczne bariery utrudniające, a nawet uniemożliwiające prowadzenie działań marketingowych. Chodzi głównie o reklamę, której stosowanie przez adwokatów jest bezwzględnie zabronione. Powstaje zatem pytanie, czy zapis zawarty w Zbiorze Zasad Etyki Adwokackiej i Godności Zawodu oraz inne regulacje ograniczające stosowanie marketingu nie powinny zostać zliberalizowane.
\end{abstract}

Słowa kluczowe: marketing usług prawniczych, marketing relacji, reklama, public relations

\section{WSTĘP}

Zwiększenie dostępu do zawodów prawniczych diametralnie zmieniło pozycję zawodową adwokatów oraz warunki świadczenia usług prawniczych. Drastycznie wzrosła liczba adwokatów i radców prawnych świadczących usługi prawne - z 27365 w 2000 roku do około 55000 w 2016 roku$^{1}$. W kolejnych latach tendencja ta ma się utrzymać. Natomiast popyt na usługi prawne utrzymuje się na stosunkowo niskim poziomie, co jest wynikiem jeszcze dość niskiej świadomości prawnej społeczeństwa. Prawnik stał się „,sprzedawcą” usług prawniczych w ramach prowadzonego przez siebie przedsiębiorstwa, co nie tylko obniżyło prestiż zawodu adwokata, ale zmusiło go do poszukiwania sposobów na wyróżnienie

1 M. Gnusowski, Konkurencyjność kancelarii prawnych. Jak zdobyć i utrzymać przewagę?, Warszawa 2017, s. 14.

Przegląd Prawa i Administracji 115, 2018

(C) for this edition by CNS 
swojej kancelarii i świadczonych w nich usług na tle konkurencji. Adwokaci coraz częściej w walce o nabywców swoich usług wykorzystują marketing usług prawniczych.

Głównym celem niniejszego artykułu jest zaprezentowanie możliwych do wykorzystania instrumentów marketingu w działalności kancelarii adwokackich. Niewątpliwie ze względu na obecne warunki funkcjonowania rynku usług prawnych aktywność marketingowa kancelarii adwokackich staje się koniecznością.

\section{REORIENTACJA PRAWNIKÓW RYNKU USŁUG PRAWNICZYCH}

Deregulacja usług prawniczych w ramach ustawy z 13 czerwca 2013 roku o zmianie ustaw regulujących wykonywanie niektórych zawodów ${ }^{1}$, obejmująca swym zakresem zastosowania między innymi ustawę z 26 maja 1982 roku $^{2}$ Prawo o adwokaturze ${ }^{3}$, ustawę z 6 lipca 1982 roku o radcach prawnych, ustawę z 14 lutego 1991 roku - Prawo o notariacie ${ }^{4}$, doprowadziła do swoistej reorientacji kancelarii prawnych z wyłącznego świadczenia usług prawnych do poszerzenia działań o marketing.

Można wyróżnić następujące fazy reorientacji kancelarii na rynku usług prawnych:

- orientacja usługowa,

- orientacja sprzedażowa,

— orientacja marketingowa (marketing relacji),

- orientacja strategiczna.

Najstarszym i obecnie przestarzałym już typem orientacji jest orientacja usługowa, której charakterystyczną cechą było ukierunkowanie działań kancelarii prawnych na udzielanie pomocy prawnej klientom. Usługi prawnicze były trudniej dostępne, a popyt na nie przewyższał podaż. Świadomość możliwości adaptacji działań marketingowych w zarządzaniu kancelarią prawną była niewielka.

$\mathrm{Na}$ etapie orientacji sprzedażowej sytuacja na rynku usług prawnym diametralnie się zmieniła. Począwszy od 2005 roku (ustawa z dnia 30 czerwca 2005 roku o zmianie ustawy - Prawo o adwokaturze i niektórych innych ustaw ${ }^{5}$ ), aż do 2013 roku (ustawa z dnia 13 czerwca 2013 roku o zmianie ustaw regulujących wykonywanie niektórych zawodów ${ }^{6}$ ) poszerzano dostęp do niektórych zawodów prawniczych. Znacznie wzrosła liczba prawników, przy nieznacznym wzroście

2 Ustawa z dnia 6 lipca 1982 roku o radcach prawnych, Dz.U. z 1982 r. Nr 19, poz. 145.

3 Ustawa z dnia 26 maja 1982 roku - Prawo o adwokaturze, Dz.U. z 1982 r. Nr 16, poz. 124.

4 Ustawa z dnia 14 lutego 1991 roku - Prawo o notariacie, Dz.U. z 1991 r. Nr 22, poz. 91.

5 Ustawa z dnia 30 czerwca 2005 roku o zmianie ustawy — Prawo o adwokaturze i niektórych innych ustaw, Dz.U. z 2005 r. Nr 163, poz. 1361.

6 Ustawa z dnia 13 czerwca 2013 roku o zmianie ustaw regulujących wykonywanie niektórych zawodów (tak zwana ustawa deregulacyjna), Dz.U. z 2013 r. poz. 829.

Przegląd Prawa i Administracji 115, 2018

(C) for this edition by CNS 
popytu na usługi prawnicze. Pojawiły się problemy ze zdobyciem klienta, przez co zwiększyła się konkurencja między kancelariami prawnymi. Jakość świadczonych usług prawnych była coraz bardziej zróżnicowana. Jednakże konkurowanie wyłącznie jakością usług stało się niewystarczające.

Prawnicy zaczęli poszukiwać sposobów na zwiększenie konkurencyjności ich kancelarii w zmieniających się warunkach funkcjonowania na rynku usług prawnych, co dało początek orientacji marketingowej. Ukierunkowali swoje działania na klienta. Pomocny w zdobywaniu klientów i utrzymywaniu z nimi relacji okazał się marketing. S. Ciupa definiuje marketing usług prawniczych jako proces orientacji prawnika na otoczenie (zwłaszcza klienta) dla rozpoznania i wykreowania jego potrzeb oraz dostarczenia i zaspokojenia dostosowanych do tych potrzeb korzyści, czy szerzej jako wartości w relacji prawnik-klient- otoczenie. Chodzi zwłaszcza o uświadomienie klientowi potrzeby skorzystania z usług prawniczych i korzyści z tego płynących ${ }^{7}$. Obecnie trudno sobie wyobrazić rynek usług prawnych bez komunikacji marketingowej. Niestety, nadal w większości przypadków podejmowane są krótkofalowe działania marketingowe.

W przyszłości niewątpliwie kancelarie prawne dostrzegą potrzebę przygotowywania długoterminowych strategii marketingowych. Przyjęcie orientacji strategicznej umożliwi kancelarii szybkie reagowanie na zmieniające się warunki funkcjonowania na rynku usług prawnych.

\section{SPECYFIKA RYNKU USŁUG PRAWNICZYCH}

Rynek usług prawnych jest rynkiem specyficznym, szczegółowo regulowanym przez normy prawne i etyczne, w tym również w odniesieniu do działalności marketingowej. Można wskazać przykładowe cechy rynku usług prawnych:

- konieczność spełnienia licznych warunków, aby uzyskać zezwolenie na świadczenie usług prawych (na przykład wymogi osobowe, wymogi w zakresie formy prowadzenia kancelarii, wymogi lokalowe czy dotyczące oznaczenia kancelarii — zgodnie z ustawą z dnia 26 maja 1982 roku — Prawo o adwokaturze oraz Regulaminem wykonywania zawodu adwokata w kancelarii indywidualnej lub spółkach);

— skomplikowany przedmiot usług prawniczych;

— przewaga podaży nad popytem;

— znaczne nasycenie rynku, duża konkurencja;

— zróżnicowanie usługodawców w zakresie wiedzy i doświadczenia;

— bariery prawne i etyczne w zakresie aktywności marketingowej;

7 S. Ciupa, W poszukiwaniu koncepcji - ksztalt zakazów etycznych obowiąujących radców prawnych $w$ obszarze marketingu i sprzedaży ustug oraz ewentualne skutki ich zniesienia, „Radca Prawny", wydanie specjalne 2007, s. 75-86. 
— zwiększająca się dysproporcja wiedzy między usługodawcą i usługobiorcą, zwłaszcza w dziedzinach związanych z wąskimi specjalizacjami prawnymi, co zdecydowanie utrudnia racjonalny wybór usługodawcy czy też ocenę jakości świadczonych usług ${ }^{8}$.

Na rynku usług prawnych konkurowanie o klienta przy użyciu instrumentów marketingowych jest w znacznym stopniu ograniczone. Adwokatów obowiązuje bezwzględny zakaz korzystania z reklamy oraz pozyskiwania klientów w sposób uwłaczający godności zawodu, zawarty w Zbiorze Zasad Etyki Adwokackiej i Godności Zawodu (Kodeksie Etyki Adwokackiej, dalej: KEA) uchwalonym przez Naczelną Radę Adwokacką, określającym reguły, które adwokaci powinni przestrzegać. W § 23 KEA czytamy, że ,adwokata obowiązuje zakaz korzystania z reklamy, jak również zakaz pozyskiwania sobie klientów w sposób sprzeczny z godnością zawodu".

Adwokat jest uprawniony wyłącznie do informowania o swojej działalności zawodowej, ale tylko pod warunkiem, że taka informacja i jej forma jest:

a) zgodna z zasadami niniejszego „Zbioru",;

b) zgodna z przepisami obowiązującymi, zwłaszcza dotyczącymi ochrony konsumentów i zwalczania nieuczciwej konkurencji;

c) dokładna i niewprowadzająca w błąd;

d) przekazywana z poszanowaniem tajemnicy zawodowej;

e) nieukierunkowana na udzielenie adwokatowi konkretnego zlecenia, z zastrzeżeniem postanowień zawartych w ust. 2 lit. b niniejszego paragrafu ${ }^{10}$.

KEA w art. 23a określa dokładnie, w jaki sposób adwokat może informować o świadczonej pomocy prawnej oraz jaką treść może zawierać taka informacja. Zgodnie z § 23a ust. 2 zgodne z KEA jest informowanie o świadczonej pomocy prawnej poprzez:

a) umieszczanie informacji na dokumentach firmowych;

b) oferty w postępowaniu o charakterze przetargu lub konkursu oraz oferty złożone na wyraźne życzenie potencjalnego klienta; w ofertach tych dozwolone jest podawanie informacji o działalności zawodowej adwokata, które mogą mieć znaczenie przy ocenie tej oferty;

c) zamieszczanie informacji prasowych bezpośrednio związanych z pomocą prawną według zasad opracowanych przez Naczelną Radę Adwokacką, a zawierających dane wymienione w ust. 3 lit. od ,a” do „i” niniejszego paragrafu;

d) zamieszczanie wpisów w książkach adresowych i telefonicznych;

8 M. Gnusowski, op. cit.

9 Zbioru Zasad Etyki Adwokackiej i Godności Zawodu.

$10 \S 23$ a pkt 2 lit b: „Adwokat może informować o świadczonej pomocy prawnej w sposób zgodny z regułami niniejszego »Zbioru« poprzez: oferty w postępowaniu o charakterze przetargu lub konkursu oraz oferty złożone na wyraźne życzenie potencjalnego klienta. W ofertach tych dozwolone jest podawanie informacji o działalności zawodowej adwokata, które mogą mieć znaczenie przy ocenie tej oferty". 
e) przesyłanie informacji za pomocą elektronicznych środków komunikacji na wyraźne życzenie potencjalnego klienta;

f) umieszczanie informacji na stronach internetowych oraz umieszczanie danych o tej stronie w katalogach i wyszukiwarkach;

g) stosowne oznaczanie siedziby kancelarii;

h) wydawanie broszur lub informatorów.

We wskazanej formie mogą być przekazane przez adwokata informacje zawierające:

a) znak towarowy lub graficzny kancelarii lub spółki;

b) nazwę i adres kancelarii oraz imię i nazwisko adwokata, numery środków łączności, adres e-mailowy oraz nazwę strony internetowej;

c) listę wspólników spółki, w której adwokat jest wspólnikiem wraz ze wskazaniem, który ze wspólników jest adwokatem, a jeśli w spółce powołane są osoby zarządzające - ich nazwiska wraz ze wskazaniem pełnionych funkcji;

d) listę osób stale współpracujących z kancelarią lub spółką;

e) tytuł lub stopień naukowy adwokata;

f) dane na temat rodzaju i zakresu świadczonej przez adwokata pomocy prawnej ze wskazaniem preferowanych dziedzin prawa oraz współpracy z kancelariami zagranicznymi;

g) dane o możliwości świadczenia pomocy prawnej w obcych językach;

h) rok założenia kancelarii lub spółki oraz datę rozpoczęcia działalności;

i) przynależność do określonej izby adwokackiej;

j) wykaz publikacji adwokata;

k) zamieszczenie informacji o posiadanych kwalifikacjach innych niż prawnicze;

1) wizerunek adwokata;

m) wyłącznie na życzenie klienta lub w ofercie skierowanej do potencjalnego klienta - oświadczenie na temat stawek wynagrodzeń i metod ich obliczania;

n) wyłącznie na życzenie klienta lub w ofercie skierowanej do potencjalnego klienta - wysokość ubezpieczenia od odpowiedzialności cywilnej (§ 23a ust. 3).

Nadto KEA za niedopuszczalne uznaje kierowanie oferty do potencjalnych klientów, jeśli wcześniej nie wyrazili oni takiego życzenia; odpłatne inspirowanie artykułów prasowych lub audycji, które pod pretekstem obiektywnej informacji mają służyć promocji adwokata, jego kancelarii lub spółki; zwracanie się do potencjalnych klientów w celu przekazywania informacji o swojej działalności, również podczas nieproszonych wizyt, rozmów telefonicznych i w korespondencji do osób niezwracających się do adwokata o pomoc prawną; zlecanie osobom trzecim rozpowszechniania informacji o adwokacie; płacenie wynagrodzenia za publikowanie informacji o jego działalności zawodowej.

Informacje zawarte $\mathrm{w}$ ofercie nie mogą:

a) stwarzać prawdopodobieństwa wywołania nieuzasadnionego oczekiwania co do wyników pracy adwokata; 
b) powoływać się na osobistą znajomość sędziów, prokuratorów i urzędników;

c) zawierać bezpośrednich porównań w zakresie jakości z innymi możliwymi do identyfikacji adwokatami i członkami innych korporacji prawniczych lub ich krytyki;

d) posługiwać się niestosowną lub natarczywą formą;

e) zawierać jakichkolwiek elementów ocennych (§ 23b).

Warto zauważyć, że ograniczenia dotyczące możliwości stosowania poszczególnych narzędzi marketingowych nie dotyczą tylko promocji. W art. 16 pkt 1 ustawy - Prawo o adwokaturze czytamy, że „Opłaty za czynności adwokackie ustala umowa z klientem", jednakże w dalszych punktach znajduje się informacja, że minister sprawiedliwości określa stawki minimalne za czynności adwokackie oraz wysokość opłat za czynności adwokackie przed organami wymiaru sprawiedliwości. Oznacza to, że konkurowanie kancelarii „cenami” jest w znacznym stopniu ograniczone. Tylko nieliczne, prestiżowe kancelarie o ugruntowanej pozycji na rynku usług prawnych mogą windować cenę znacznie powyżej stawki minimalnej.

Nadto zarówno informacja, jak i oferta powinny być dystrybuowane w sposób właściwy, czyli nienatarczywy i stosowny, tak aby nie naruszyć godności zawodu adwokata.

\section{DZIAŁALNOŚĆ MARKETINGOWA KANCELARII ADWOKACKICH}

Jak podkreślono, wśród prawników (adwokatów i radców prawnych) rośnie świadomość konieczności stosowania marketingu w działalności ich kancelarii. Zasadniczym celem podejmowanej aktywności marketingowej jest nie tylko pozyskanie klientów, lecz także ich utrzymanie. Dlatego też coraz częściej mówi się o marketingu relacji (relationship marketing) na rynku usług prawniczych, czyli tworzeniu, utrzymywaniu i wzbogacaniu relacji z klientem ${ }^{11}$. Działania marketingowe są niezwykle ważne w budowaniu wizerunku kancelarii adwokackich, oczywiście wspierane wiedzą i kompetencjami adwokatów w niej pracujących.

Sposób realizacji celów marketingowych jest różny i zależy głownie od wielkości kancelarii. O profesjonalność działań marketingowych dużych kancelarii adwokackich dbają obecnie agencji marketingowe specjalizujących się w marketingu prawniczym oraz specjaliści od PR. Mniejsze kancelarie podejmują działania marketingowe często jeszcze w sposób intuicyjny i krótkofalowy.

Obecnie każda kancelaria adwokacka korzysta z nowoczesnych form komunikacji, ma własną stronę internetową, profile na portalach społecznościowych, takich jak Facebook czy Twitter, w profesjonalnych serwisach zrzeszających specjalistów z różnych dziedzin — Linkedin, Goldenline; coraz więcej adwokatów

11 M. Christopher, A. Payne, D. Ballantyne, Relationship Marketing, Oxford 1991, s. 9. 
prowadzi blogi, na których publikowane są autorskie teksty, a także wideoblogi na YouTubie. Dyskusyjną kwestią jest możliwość pozycjonowania stron poprzez umieszczanie danych o stronie w katalogach i wyszukiwarkach internetowych. Tę formę informowania należy jednak uznać za dozwoloną ${ }^{12}$. Za niedopuszczalne uznaje się kierowanie drogą mailową oferty do potencjalnych klientów, którzy nie wyrazili takiego życzenia ( $\$ 23 \mathrm{~b}$ ust. $4 \mathrm{KEA}$ ). Odmiennie należy ocenić proponowanie czytelnikowi bloga zapisanie się do newslettera zawierającego publikowane artykuły adwokata i podstawowe dane o kancelarii.

Nie oznacza to jednak, że adwokaci nie korzystają z klasycznych mediów, takich jak prasa, radio czy telewizja. Niestety możliwość ich wykorzystania $\mathrm{w}$ przeciwieństwie do internetu — jest w znacznym stopniu ograniczona przez KEA. Adwokaci mogą zamieszczać informacje prasowe tylko bezpośrednio związane z pomocą prawną i wyłącznie według reguł określonych uchwałą Prezydium Naczelnej Rady Adwokackiej nr 48/2006 z dnia 7 marca 2006 roku w sprawie zasad zamieszczania informacji prasowych bezpośrednio związanych z pomocą prawną świadczoną przez adwokata. Zgodnie z nią adwokat może umieszczać ogłoszenia prasowe zawierające dane wymienione w ust. 3 lit. a-i KEA w formie ogłoszenia o rozmiarach nie większych niż $1 / 10$ strony dziennika lub czasopisma, z wyłączeniem stron od 1 do 3 oraz okładek, i nie częściej niż raz w miesiącu w danym dzienniku lub czasopiśmie oraz nie więcej niż w trzech tytułach prasowych w miesiącu. Nadto zalecane jest, dla odróżnienia ogłoszeń o pomocy prawnej świadczonej przez podmioty inne niż adwokat, zamieszczanie w ogłoszeniu znaku Adwokatury Polskiej, dostępnego nieodpłatnie w formie elektronicznej w Naczelnej Radzie Adwokackiej. Adwokat może pokrywać wyłącznie koszty publikacji, zabronione jest płacenie wynagrodzenia.

Tym, co sprawdza się zwłaszcza w małych — zazwyczaj jednoosobowych — kancelariach, jest stosowanie identyfikacji wizualnej — logo kancelarii, wygląd dokumentów firmowych, wydawanie broszur, informatorów, zamieszczanie wpisów w książkach adresowych, telefonicznych, czy branżowych, gadżety reklamowe (długopisy, kalendarze), duży i solidny szyld, lokalizacja biura. Należy zauważyć, że w kwestii oznakowania kancelarii adwokaci nie mają pełnej swobody działania. Oznaczenie siedziby kancelarii musi być „stosowne” (§ 23a ust. 2 lit. g KEA), czyli skromne i powściągliwe w formie. Poza tym $\S 4$ ust. 4-6 Regulaminu wykonywania zawodu adwokata w kancelarii indywidualnej lub spółkach ${ }^{13}$ wskazuje sposób oznaczenia lokalu, w którym adwokat wykonuje swój zawód:

12 Chociażby ze względu na treść najnowszego orzeczenia WSD z dnia 22 października 2016 roku, sygn. WSD 120/15.

13 Uchwała nr 38/2015 Naczelnej Rady Adwokackiej z dnia 27 czerwca 2015 roku w sprawie Regulaminu wykonywania zawodu adwokata w kancelarii indywidualnej lub spółkach, http://www. nra.pl/dokumenty.php?pgnum=28\&sort=2\&limit=10\&datado=3000 (dostęp: 13.07.2017). 
Lokal powinien być oznaczony zgodnie z obowiązującymi przepisami, z tym że oznaczenie winno wskazywać w sposób niebudzący wątpliwości na wykonywanie w tym lokalu zawodu adwokata, przez użycie słów „adwokat”, ,adwokaci”, ,adwokacki” w dowolnej formie gramatycznej. W odniesieniu do spółek z niewyłącznym udziałem adwokatów wystarczające jest podanie firmy spółki z oznaczeniem „spółka prawnicza” lub podobnym, chyba że firma spółki, ze względu na jej brzmienie lub utrwaloną renomę, nie wprowadza w błąd co do charakteru prowadzonej przez spółkę działalności. Powyższe oznaczenia możliwe są również w języku obcym.

\section{I dalej:}

Oznaczenie lokalu nie powinno stwarzać wrażenia, jakoby adwokat lub spółka, w której wykonuje on zawód, prowadzili działalność inną niż świadczenie pomocy prawnej ani jakoby ich działalność była w jakikolwiek sposób związana z działalnością podmiotu, który nie jest adwokatem lub spółką z udziałem adwokata. Zabrania się adwokatowi wyrażania zgody na firmowanie działalności zarobkowej innej niż wykonywanie zawodu adwokata, radcy prawnego lub prawnika zagranicznego prowadzącego działalność na podstawie ustawy o świadczeniu przez prawników zagranicznych pomocy prawnej w Rzeczypospolitej Polskiej.

Nadto

lokal filii powinien być oznaczony nazwą kancelarii adwokackiej z dodaniem słowa „filia”. Lokal oddziału powinien być oznaczony firmą spółki, której jest oddziałem z dodaniem słowa „oddział”.

Adwokat, dokonując wyboru lokalu na siedzibę kancelarii, musi zadbać, aby był on „odpowiedni”. Powinien w szczególności odpowiadać wymogom godności i zasad wykonywania zawodu oraz zapewniać klientom dyskrecję (§ 4 ust. 1). Wybór odpowiedniego lokalu jest równie istotny z marketingowego punktu widzenia. Lokalizacja biura, jego wnętrze i atmosfera przy pierwszym spotkaniu podlegają ocenie klienta.

Zarządzanie kancelarią adwokacką w znacznej mierze opiera się na budowaniu pozytywnych relacji z opinią publiczną oraz obecnymi i potencjalnymi klientami, czyli public relations. Niewątpliwie najskuteczniejszy PR kancelarii tworzą jej pracownicy. Po pierwsze, przez odpowiednią komunikację z klientem, która zdaniem D. Hołubiec polega na uważnym wysłuchaniu i mówieniu zrozumiałym dla klienta językiem ${ }^{14}$. Umiejętność nawiązywania, a także pielęgnowania kontaktu z klientami daje efekty w postaci dalszej rekomendacji prawnika. KEA zabrania bowiem wyłącznie zlecania osobom trzecim rozpowszechniania informacji o adwokacie ( $§ 23$ b ust. 5). Po drugie, ważna jest wysoka jakość świadczonej pomocy prawnej. Adwokaci publikujący swoje artykuły w cenionych czasopismach prawniczych, współpracujący z mediami w charakterze ekspertów, uczestniczący w konferencjach, seminariach w roli prelegentów, będący członkami samorządu adwokackiego, stowarzyszeń, izb gospodarczych, udzielający pomocy prawnej publico bono itp. budują markę i wizerunek kancelarii. Zdaniem D. Hołubiec naj-

14 D. Hołubiec, Marketing to dobra inwestycja w kancelarię prawna, „Rzeczpospolita” 22.06.2007, http://www.rp.pl/artykul/57968-Marketing-to-dobra-inwestycja-w-kancelarie-prawna. $\mathrm{html}$. 
lepszym narzędziem profesjonalnego marketingu są sami prawnicy. Wizerunek dobrego prawnika automatycznie kojarzy się z dobrą kancelarią, a profesjonalizm kancelarii buduje się na profesjonalizmie wszystkich ludzi w niej pracujących ${ }^{15}$.

\section{WNIOSKI}

Niewątpliwie zawarte w KEA ograniczenia w zakresie stosowania reklamy nie pasują do obecnych realiów funkcjonowania rynku usług prawniczych. Dlatego też adwokaci (oraz członkowie innych samorządów zawodowych) coraz częściej poszukują narzędzi alternatywnych dla reklamy, umożliwiających zdobycie i utrzymanie pozytywnych relacji z klientami, korzystając w tym celu z marketingu usług prawniczych.

Co więcej, wydaje się, że samo środowisko adwokackie dostrzega potrzebę zmian. Najnowsze orzecznictwo również zmierza w kierunku liberalizacji § 23 KEA wprowadzającego bezwzględny zakaz korzystania z reklamy. Na zakończenie należy przytoczyć przełomowe i wymowne orzeczenie Wyższego Sądu Dyscyplinarnego z dnia 22 października 2016 roku, sygn. WSD 120/15, w którym WSD sformułował następujący pogląd prawny:

Sądy dyscyplinarne izb adwokackich oraz Wyższy Sąd Dyscyplinarny jako organy powołane ustawą do orzekania w przedmiocie odpowiedzialności dyscyplinarnej adwokatów i aplikantów adwokackich zdefiniowanej w art. 80 ustawy Prawo o adwokaturze oraz z mocy art. 17 ust. 1 Konstytucji RP sprawujące pieczę nad należytym wykonywaniem zawodu adwokata w granicach interesu publicznego i dla jego ochrony zobowiązane są do uwzględnienia treści art. 24 ust. 1 Dyrektywy 2006/123/WE Parlamentu Europejskiego i Rady z dnia 12 grudnia 2006 r. dotyczącej usług na rynku wewnętrznym w procesie dekodowania normy sankcjonowanej na potrzeby rozstrzygnięcia o odpowiedzialności indywidualnej adwokata za zachowanie polegające na korzystaniu z reklamy. Tym samym oznacza to, że norma sankcjonowana w tym wypadku nie może zawierać, jak ma to miejsce w wypadku § 23 ZZEAiGZ (KEA), zakazu całkowitego (bezwzględnego), albowiem pozostawałoby to w nieusuwalnej sprzeczności ze znajdującym w tym wypadku bezpośrednie zastosowanie prawem wspólnotowym. Przyjąć należy zatem, że dekodowana norma sankcjonowana uwzględniać musi — co najmniej do czasu zmiany przez Naczelną Radę Adwokacką treści zasady zawartej w $§ 23$ ZZEAiGZ (KEA) — także normę art. 80 ustawy Prawo o adwokaturze oraz art. 24 ust. 2 Dyrektywy. Oznaczać to będzie przyjęcie odpowiedzialności dyscyplinarnej nie za każde korzystanie z reklamy, ale za takie z niej korzystanie, które będzie sprzeczne z obowiązującym w tym zakresie prawem publicznym (w tym także wspólnotowym), sprzeczne z ciążącymi na adwokacie obowiązkami zawodowymi oraz z zasadami etyki i godnością zawodu, w szczególności zaś naruszające zasady niezależności, godności i uczciwości zawodowej, naruszające tajemnicę zawodową i inne zasady dotyczące wykonywania zawodu adwokata jako zawodu o szczególnym charakterze ${ }^{16}$.

\section{Ibidem.}

16 Orzeczenie WSD z dnia 22 października 2016 roku, sygn. WSD 120/15, http://wsd.adwokatura.pl/aktualnosci/114-zakaz-reklamy-wyzszy-sad-dyscyplinarny-adwokatury-o-korzystaniu-z-uslugi-adwords (dostęp: 4.07.2017).

Przegląd Prawa i Administracji 115, 2018

(C) for this edition by CNS 


\section{BIBLIOGRAFIA}

Christopher M., Payne A., Ballantyne D., Relationship Marketing, Oxford 1991.

Ciupa S., W poszukiwaniu koncepcji - kształt zakazów etycznych obowiąujacych radców prawnych w obszarze marketingu i sprzedaży ustug oraz ewentualne skutki ich zniesienia, „Radca Prawny” 2007, wydanie specjalne.

Gnusowski M., Konkurencyjność kancelarii prawych. Jak zdobyć i utrzymać przewagę?, Warszawa 2017.

Hołubiec D., Marketing to dobra inwestycja w kancelarie prawna, „Rzeczpospolita” 22.06.2007, http://www.rp.pl/artykul/57968-Marketing-to-dobra-inwestycja-w-kancelarie-prawna.html.

\section{AKTY PRAWNE}

Orzeczenie WSD z dnia 22 października 2016 roku, sygn. WSD 120/15, http://wsd.adwokatura. pl/aktualnosci/114-zakaz-reklamy-wyzszy-sad-dyscyplinarny-adwokatury-o-korzystaniu-zuslugi-adwords.

Uchwała nr 38/2015 Naczelnej Rady Adwokackiej z dnia 27 czerwca 2015 roku w sprawie Regulaminu wykonywania zawodu adwokata w kancelarii indywidualnej lub spółkach.

Ustawa z dnia 26 maja 1982 roku — Prawo o adwokaturze, Dz.U. z 1982 r. Nr 16, poz. 124.

Ustawa z dnia 6 lipca 1982 roku o radcach prawnych, Dz.U. z 1982 r. Nr 19, poz. 145.

Ustawa z dnia 14 lutego 1991 roku — Prawo o notariacie, Dz.U. z 1991 r. Nr 22, poz. 91.

Ustawa z dnia 30 czerwca 2005 roku o zmianie ustawy - Prawo o adwokaturze i niektórych innych ustaw, Dz.U. z 2005 r. Nr 163, poz. 1361.

Ustawa z dnia 13 czerwca 2013 roku o zmianie ustaw regulujących wykonywanie niektórych zawodów (tak zwana ustawa deregulacyjna), Dz.U. z 2013 r. poz. 829.

\section{AN ABSOLUTE BAN ON THE ADVERTISING OF LAWYER'S OFFICES IN THE REALITIES OF THE CONTEMPORARY FUNCTIONING OF THE LEGAL SERVICES MARKET}

\section{Summary}

Running a lawyer's office in the current realities of the legal services market is a challenge. An advocate must possess not only legal knowledge but also demonstrate knowledge of market mechanisms. Nowadays, the client decides which lawyer to choose, and this forces lawyers to take action in order to acquire and maintain clients. Hence, marketing instruments (typical for other service markets) are increasingly used to build and achieve market advantage. However, there are numerous barriers on the legal services market that hinder or even prevent extensive marketing activities. Advertising is the main concern here, as its use by attorneys is strictly prohibited. The question arises as to whether in the present reality the provision contained in the Collection of Rules on Barrister's Ethics and Dignity of Profession and other regulations limiting the use of marketing should not be subject to liberalization.

Keywords: legal services marketing, relationship marketing, advertising, public relations 